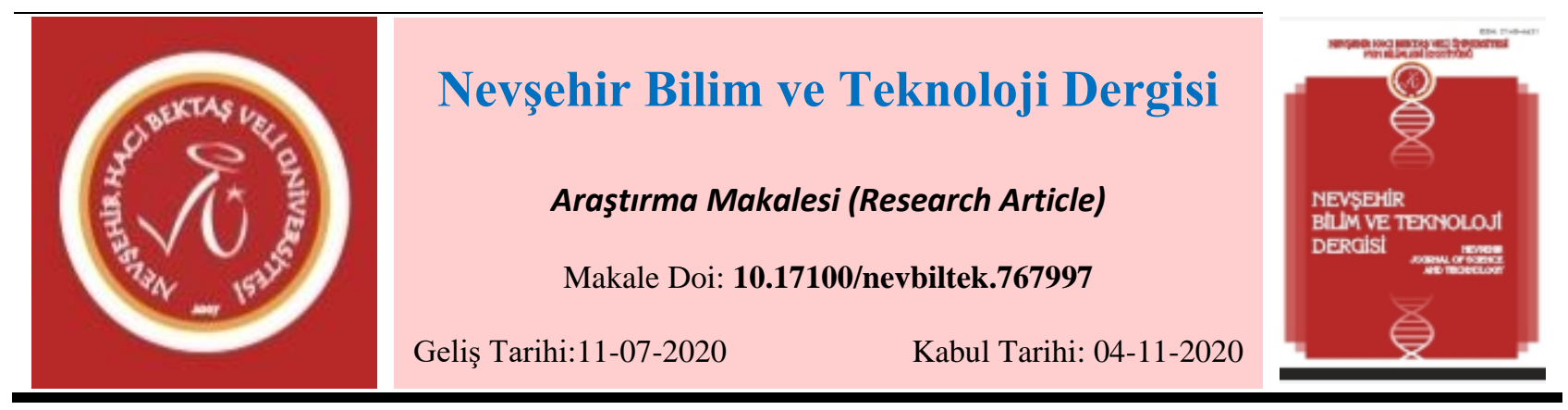

\title{
Hibrid Mısır Çeşitlerinin Koçan Özellikleri ve Tane Kalite Kriterlerinin Belirlenmesi
}

\author{
Leyla İDIKUT ${ }^{1 *}$, Mehmet EKINCI' ${ }^{2}$, Cafer GENÇOLAN ${ }^{3}$ \\ ${ }^{1}$ Kahramanmaraş Sütçü İmam Üniversitesi, Ziraat Fakültesi, Tarla Bitkileri Bölümü, 46100, Kahramanmaraş, Türkiye \\ ORCID 0000-0002-0685-7158, \\ 2Toprak Mahsulleri Ofisi, Kırklareli Şubesi, 39020, Kırklareli, Türkiye \\ ORCID: 0000-0003-4717-737 \\ ${ }^{3}$ Kahramanmaraş Sütçü İmam Üniversitesi, Ziraat Fakültesi, Biyosistem Mühendisliği Bölümü, 46100, \\ Kahramanmaraş, Türkiye \\ ORCID:0000-0002-4559-4354
}

Öz

Mısır bitkisinde yeni hibrit çeşitlerinin sürekli piyasaya arzı, bölge koşullarında denenmesinin gerekliliğini zorunlu hale getirmektedir. Bu amaçla, Kahramanmaraş koşullarında 2016 yılı ikinci ürün sezonunda, Tavascan, Motri, Calgary, Sancia, P.573, P.32T83, Hydro, Performer, Capuzi, 72MAY80, Simon, Macha, PL 712, Torro, Bolsan, KB 5562, KB 3961 hibrit mısır çeşitlerinin koçan özellikleri ve tane kalite karakterleri araştırılmıştır. Araştırma tesadüf blokları deneme desenine göre 3 tekerrürlü olarak yürütülmüştür. Hibrid mısır çeşitlerinin koçan püskülü çıkış süresinin 52.0 - 59.0 gün, koçan yüksekliğinin 53.7 - $89.7 \mathrm{~cm}$, koçan uzunluğunun 16.9 - $22.2 \mathrm{~cm}$, koçan çapının 43.5-49.5 mm, koçanda sıra sayılarının 14.5 - 16.9 adet, koçan sırasında tane sayılarının 31.6 - 45.0 adet, koçan tane ağırlıklarının 114.8 - $219.6 \mathrm{~g}$, koçan tane oranlarının \% 84.1 -89.5, bin tane ağırlıklarının 274.0 - $383.9 \mathrm{~g}$, tanede protein oranlarının \% 7.6-9.6, nişasta oranlarının \% 65.5-69.6, yağ oranlarının \% 2.4-3.5 arasında değiștiği tespit edilmiş̧tir. Çeşitler arasında tüm incelenen özellikler yönünden $\mathrm{P}=0.01$ düzeyinde istatistiksel önemli farklılığın olduğu kaydedilmiş̧ir. Bir yıllık araştırma sonucuna göre; protein yönünden Bolsan, Tavascan, 72MAY80, Torro, PL712 hibrit mısır çeşitlerinin, nişasta yönünden P.573, KB3961, Capuzi ve Sancia çeşitlerinin, taze tüketim için uzun koçana sahip Calgary, Hydro ve Simon çeşitlerinin önerilmesi uygun görülmüştür.

Anahtar Kelimeler: Mısır, koçan, tane özellikleri.

\section{Determination of Ear Characteristics and Grain Quality Criteria of Hybrid Corn Varieties}

\begin{abstract}
The corn plant are required the necessity of testing in regional conditions, because new hybrid varieties are continuous submission of to the market. For this purpose, ear characteristics and grain quality criteria of hybrid maize varieties (Tavascan, Motri, Calgary, Sancia, P.573, P.32T83, Hydro, Performer, Capuzi, 72MAY80, Simon, Macha, PL 712, Torro, Bolsan, KB 5562, KB 3961) were investigated in the second crop season growing in 2016 under Kahramanmaraş conditions. The study was carried out with 3 replications according to random blocks the trial model. It was determined that ear silk period, first ear height, ear length, ear diameter, the row number of ear, the number of grain on the ear row, grain weight of ear, grain ratio of cob, 1000 grain weight, protein ratio, starch ratio and oil ratio ranged from 52.0-59.0 day, 53.7-89.7 cm, 16.9-22.2 cm, 43.5-49.5 mm, 14.5-16.9, $31.6-45.0,114.8-219.6 \mathrm{~g}, 84.1-89.5 \%, 274.0-383.9 \mathrm{~g}, 7.6-9.6 \%, 65.5-69.6 \%, 2.4-3.5 \%$ respectively. It was noted that there was a statistically significant difference of $\mathrm{P}=0.01$ in terms of all studied characteristics among cultivars. According to one-year research results; It are recommended as appropriate Bolsan, Tavascan, 72MAY80, Torro, PL712 hybrid corn varieties in terms of protein, P.573, KB3961, Capuzi and Sancia varieties in terms of starch, Calgary, Hydro and Simon varieties with long cob for fresh consumption.
\end{abstract}

Keywords: Corn, ear, grain characteristics.

*Sorumlu yazar e-posta: leylaidikut@gmail.com ; lcesurer@ksu.du.tr 
Nevşehir Bilim ve Teknoloji Dergisi (2020), 9(2) 142-153

\section{Giriş}

Tarım kelimesi daima üretimi çağrıştıran bir terimdir. Üretim ise alt yapının (toprak, alet, ekipman, tohum, gübre v.s) ve bilgi birimin bileşimidir. Alt yapı finansal güçle sağlanmaktadır. Toprak, alet, ekipman, tarımda finansal gücü oluşturan unsurlardır. Bilgi birikimi araştırılarak ve deneyerek elde edilmektedir. Tarımda her geçen gün alt yapı ve bilgi birikimi artarak devam etmektedir. Bu gelişme üretilen ürünün daha çok üretilmesi, bölgeye uyum sağlayan çeşitlerin artırılması ve kalite kriterlerinin bilinmesini sağlamaktadır. Tarım ürünleri içinde bu gelişmeye en hızlı uyum sağlayan bitkilerden biri mısır bitkisidir. Dünya'da mısır verimi $592 \mathrm{~kg} \mathrm{da}^{-1}$, üretim 1.147.621. bin ton ve hasat edilen alan 193.733.568 ha'dır [1]. Türkiye'de 2019 yılı için mısır ekim alanı 638.828 hektar üretim 6000000 ton'dur, Kahramanmaraş’ta ekim alanı 24.026 hektardır[2]. Yaz sezonu kısa olan bölgelerde birinci ürün veya silaj bitkisi olarak tarımı yapılırken, yaz sezonu uzun bölgelerde hem birinci ürün, hem de ikinci ürün olarak üretimi yapılmaktadır. Bitki sıcağı sevmesine rağmen sıcaklık stresi morfolojik özellikleri üzerinde çeşitler arasında yüksek genetik varyasyona neden olmaktadır. Çiçeklenme döneminde sıcaklık stresinin koçan püskülü üzerine etkisini, tepe püskülünde daha yüksek olduğu bildirilmiştir. Mısır verimine etkili olan bitkide koçan sayısı, koçan uzunluğu, koçan çapı, koçan yüksekliği, koçan sıra sayısı ve sırada tane sayısı üzerine sıcak stresinin olduğu kaydedilmiştir[3].Mısır bitkisi koçandaki tane gelişimi tamamlamada çevresel faktörlerdeki değişimini telafi etmede çok yönlü üretim faktörüne sahip bir bitkidir[4]. Birim alandaki koçan sayısı, koçandaki tane sayısı, bin tane ağırlığı özelikleri mısır bitkisinin tane verimini belirleyen üç ana faktörü oluşturduğu kaydedilmiştir[5]. İnsan besini, etanol üretimi, nişasta, yağ üretimi gibi durumlara göre kullanılacak mısır çeşitlerinin farklılık gösterdiği, aynı çeşidin farklı sanayi ürünü olarak kullanımında ekonomik değerlendirmenin dikkate alınması gerekliliği vurgulanmıştır[6]. Mısır tanesinin anatomik bölümlerinin mikro yapısal özelliklerinin bilinmesi, tüm endüstriyel segmentlerin nihai ürünlerinin kalite ve verimini yakından ilgilendirdiği için son derece önemli olduğu belirtilmiştir. Mısırın makro ve mikro yapısal özelliklerinin daha iyi anlaşılması, mısırın birçok gıda ve endüstriyel üründe kullanma imkanlarının geliştirmesine destek verecektir. Hasat, kurutma, depolama ve işlemede optimum kalitenin koruması sağlanacaktır[7]. Mısır bitkisinin monocieous (tek evcikli) olması melez çalışmalara firsat vermektedir. Bu nedenle, her yıl yeni mısır çeşitlerinin piyasaya arzı artmaktadır. Yeni çeşitlerin geliştirilmesinde sürekliliğin devam etmesi, mısırın kısa sürede yetişmesi, tarımının mekanize olması ve sanayide (un mamulleri, çerez, yem, bitkisel yağlar, nişasta, enerji gibi alanlarda) kullanımının armasından kaynaklanmaktadır. Mısır bitkisinin sanayide farklı kullanım amaçlarıyla değerlendirilmesi, kullanılacak ürünün kalite özeliklerinin bilinmesini gerektirmektedir. Bu amaçla, Kahramanmaraş koşullarında ikinci ürün olarak yetiştirilen 17 hibrit mısır çeşidinin koçan ve tane özellikleri incelenmiştir.

\section{Materyal ve Metot}

Araştırma, Kahramanmaraş koşullarında, 2016 yılında, ikinci ürün yetiştirme sezonunda yürütülmüştür. Denemede materyal olarak Tavascan, Motri, Calgary, Sancia, P.573, P.32T83, Hydro, Performer, Capuzi, 72MAY80, Simon, Macha, PL712, Torro, Bolsan, KB5562 ve KB3961 hibrit mısır çeşitlerin kapsayan toplam 17 (FAO 500-550 olum grubundaki) çeşitler kullanılmıştır. Araştırma tesadüf blokları deneme deseninde uygun üç tekerrürlü olarak yürütülmüsştür. Mısır çeşitlerinin tohum ekimi 1 Temmuz 2016 tarihinde 70X20 cm bitki sıklığında yapılmıştır. Denemede her bir parsel dört sıra ve $5 \mathrm{~m}$ uzunluğu kapsayan $14 \mathrm{~m}^{2}$ alandan oluşmuştur. Ekimle birlikte net $6 \mathrm{~kg} \mathrm{da}^{-1}$ fosfor ve azot (20-20-0: N:P:K) gübresi uygulanmıştır. Daha sonra azot(üre) üst gübre olarak uygulanarak $25 \mathrm{~kg} \mathrm{da}^{-1}$ tamamlanmıştır(8). Hasat yağışlardan dolayı gecikmiş ve 9 Kasım'da elle yapılmıştır. Çeşitlerin koçan püskülü çıkış süresi, koçan yüksekliği, koçan uzunluğu, koçan çapı, koçanda sıra sayısı, koçan sırasında tane sayısı, koçanda tane ağırlığı, tane oranı, bin tane ağırlı̆̆ı, tanede protein oranı, nişasta oranı ve yağ oranı özellikleri araştırılmıştır (9) Araştırmanın yürütüldüğü alanın 0-30 cm derinliğinden toprak örnekleri alınmıştır. Alınan toprak örneğinin kumlu killi tınlı tekstürlü bünyeye sahip olduğu, pH'sı 7.55, organik madde oranının 1.52, elverişli potasyum miktarının $74.72 \mathrm{~kg}$ da-1, kireç oranı \%15.71, elverişli fosfor 
Nevşehir Bilim ve Teknoloji Dergisi (2020), 9(2) 142-153

miktarının 5.44 kg da-1 olduğu kaydedilmiştir[10]. İkinci ürün mısır bitkisinin yetişme süresinde (2016), Kahramanmaraş koşullarında(Temmuz, Ağustos ve Eylül aylarında) maksimum sıcaklık ortalamasının 23-38 ${ }^{\circ} \mathrm{C}$, minimum sıcaklık ortalamasının $14-24{ }^{\circ} \mathrm{C}$, sıcaklık ortalamasının $24-30{ }^{\circ} \mathrm{C}$, nisbi nemin \% 36-42 arasında değiştiği, Temmuz ve Ağustos aylarında hiç yağış olmadığı, sadece Eylül ayında $23.7 \mathrm{~mm}$ yağışın düştüğü rapor edilmiştir[11]. Bu nedenle, bitkilerin su ihtiyacı 10 günlük periyotlarla 8 kez karık usulü sulama yöntemi ile karşılanmıştır. Araştırmada elde edilen veriler SAS istatistiki paket programı kullanılarak analiz edilmiş, ortalamalar arasındaki farklılıklar Duncan $(\mathrm{P}<0.05)$ çoklu karşılaştırma testine göre gruplanmıştır.

\section{Bulgular ve Tartışma}

Tablo 1. İkinci ürün hibrit mısır çeşitlerinin koçan püskülü çıkış süresi, ilk koçan yüksekliği, koçan uzunluğu, koçan çapı, koçanda sıra sayısı, koçan sırasında tane sayısına ait ortalamalar ve grupları

\begin{tabular}{|c|c|c|c|c|c|c|}
\hline Çeşitler & $\begin{array}{l}\text { Koçan Püs. Çık. } \\
\text { Süre. (gün)** }\end{array}$ & $\begin{array}{l}\text { İlk Koçan Yüksek } \\
(\mathrm{cm})^{* *}\end{array}$ & $\begin{array}{l}\text { Koçan } \\
\text { Uzun. }(\mathrm{cm})^{* *}\end{array}$ & $\begin{array}{l}\text { Koçan Çap1 } \\
(\mathrm{mm})^{* *}\end{array}$ & $\begin{array}{l}\text { Koçan.Sıra Say. } \\
\text { (adet)** }\end{array}$ & $\begin{array}{l}\text { Koçan Sira..Tane } \\
\text { Sayısı(adet)** }\end{array}$ \\
\hline Tavascan & $55.0 \mathrm{c}$ & $64.8 \mathrm{~cd}$ & $22.0 \mathrm{ab}$ & $48.6 \mathrm{abc}$ & $16.8 \mathrm{ab}$ & $40.5 \mathrm{bcd}$ \\
\hline Motri & $55.0 \mathrm{c}$ & $73.3 \mathrm{bc}$ & $20.4 \mathrm{~d}$ & $44.1 \mathrm{~h} 1$ & $15.3 \mathrm{def}$ & $38.9 \mathrm{bcd}$ \\
\hline Calgary & $59.0 \mathrm{a}$ & $66.6 \mathrm{~cd}$ & $22.2 \mathrm{a}$ & 46.9 ef & 16.0 a-e & $42.1 \mathrm{abc}$ \\
\hline Sancia & $55.0 \mathrm{c}$ & $62.8 \mathrm{~cd}$ & $21.5 \mathrm{bc}$ & $49.2 \mathrm{a}$ & $15.5 c-f$ & $41.9 \mathrm{abc}$ \\
\hline P.573 & $52.0 \mathrm{~d}$ & $65.1 \mathrm{~cd}$ & $18.5 \mathrm{~g}$ & $44.1 \mathrm{~h} 1$ & $15.3 \mathrm{def}$ & $31.6 \mathrm{f}$ \\
\hline P.32T83 & $55.0 \mathrm{c}$ & $62.6 \mathrm{~cd}$ & $20.3 \mathrm{~d}$ & 43.51 & $16.5 \mathrm{abc}$ & $38.3 \mathrm{~cd}$ \\
\hline Hydro & $59.0 \mathrm{a}$ & $71.1 \mathrm{c}$ & $22.2 \mathrm{a}$ & $46.9 \mathrm{ef}$ & $14.5 \mathrm{f}$ & $41.1 \mathrm{a}-\mathrm{d}$ \\
\hline Performer & $52.0 \mathrm{~d}$ & $53.7 \mathrm{~d}$ & $19.6 \mathrm{f}$ & $48.6 \mathrm{abc}$ & $15.7 \mathrm{~b}-\mathrm{e}$ & $38.1 \mathrm{cde}$ \\
\hline Capuzi & $52.0 \mathrm{~d}$ & $65.6 \mathrm{~cd}$ & $16.9 \mathrm{~h}$ & $46.3 \mathrm{fg}$ & $16.1 \mathrm{a}-\mathrm{d}$ & $34.3 \mathrm{ef}$ \\
\hline 72May80 & $55.0 \mathrm{c}$ & $72.3 \mathrm{bc}$ & $21.1 \mathrm{c}$ & $45.8 \mathrm{~g}$ & $14.5 \mathrm{f}$ & $40.2 \mathrm{bcd}$ \\
\hline Simon & $59.0 \mathrm{a}$ & $86.2 \mathrm{a}$ & $22.1 \mathrm{a}$ & $48.2 \mathrm{bcd}$ & 16.0 a-e & $45.0 \mathrm{a}$ \\
\hline Macha & $55.0 \mathrm{c}$ & $89.7 \mathrm{a}$ & $20.0 \mathrm{de}$ & $44.8 \mathrm{~h}$ & $16.1 \mathrm{a}-\mathrm{e}$ & $38.7 \mathrm{bcd}$ \\
\hline PL712 & $55.0 \mathrm{c}$ & $73.1 \mathrm{bc}$ & $21.3 \mathrm{c}$ & $45.9 \mathrm{~g}$ & $16.9 \mathrm{a}$ & $39.3 \mathrm{bcd}$ \\
\hline Torro & $56.3 \mathrm{~b}$ & $68.3 \mathrm{c}$ & $21.5 b c$ & $49.5 \mathrm{a}$ & 16.0 a-e & $38.9 \mathrm{bcd}$ \\
\hline Bolsan & $55.0 \mathrm{c}$ & $83.9 \mathrm{ab}$ & $21.1 \mathrm{c}$ & $48.9 \mathrm{ab}$ & $16.9 \mathrm{a}$ & $42.9 \mathrm{ab}$ \\
\hline KB 5562 & $59.0 \mathrm{a}$ & $67.1 \mathrm{c}$ & $19.9 \mathrm{de}$ & 47.7 cde & 14.9 ef & $37.2 \mathrm{de}$ \\
\hline \multirow[t]{2}{*}{ KB 3961} & $55.0 \mathrm{c}$ & $69.1 \mathrm{c}$ & $19.6 \mathrm{ef}$ & $47.6 \mathrm{de}$ & $15.5 \mathrm{c}-\mathrm{f}$ & $44.9 \mathrm{a}$ \\
\hline & 55.5 & 70.3 & 20.6 & 46.9 & 15.2 & 39.6 \\
\hline
\end{tabular}

** (P $\leq 0.01)$, * Her sütunda aynı harfle gösterilen ortalamalar arasında 0.01 önem düzeyine göre fark yoktur.

\subsection{Koçan püskü̈lü çıkış süresi (gün)}

Kahramanmaraş koşullarında ikinci ürün olarak yetiştirilen 17 hibrit mısır çeşidiyle yapılan çalışmada, koçan püskülü çıkış süresinin 52.0 - 59.0 gün arasında değiştiği, çeşitlerin ortalaması 55.5 gün olarak kaydedilmiştir. Koçan püskülü çıkış süresi yönünden 17 hibrit mısır çeşitleri birbirlerinden istatistiki olarak farklı dört grup oluşturduğu görülmüştür. En erken koçan püskülü 52 günle P.573, Performer, Capuzi çeşitlerinde olduğu ve diğerlerinden istatistiki olarak önemli farklılık oluşturduğu görülmüştür En geç koçan püskülü çıkış süresi 59.0 gün ile Calgary, Hydro, Simon ve KB5562 çeşitlerinde gerçekleştiği, diğerlerinden istatistiki olarak önemli derecede farklılık oluşturduğu grupta yer aldığı kaydedilmiştir. Torro çeşidi 56.3 günde koçan püskülü çıkışı gerçekleştirdiği ve diğer çeşitlerden istatistiki olarak önemli farklılık gösterdiği tespit edilmiştir. Tavascan, Motri, Sancia, P. 32T83, 72MAY80, Marca, PL712, Bolsan, KB3961 hibrit mısır çeşitleri 55 günde koçan püskülü çıkışı gerçekleştirerek, diğerlerinden istatistiki olarak önemli derecede farklı bir grupta yer aldığı belirlenmiştir (Tablo 1). Yapılan çalışmalarda, mısır bitkisinde koçan püskülü çıkarma süresinin; Kahramanmaraş koşularında ikinci ürün mısır çeşidinde ön bitkiye ve yıllara göre 42-55 gün[8], Çanakkale koşullarında üç yerel cin mısırında 55-77 gün[12], Kahramanmaraş koşularında ikinci ürün mısır çeşitlerinde 49-60 gün[13], Kahramanmaraş koşularında birinci ürün cin mısır varyetelerinde 58-70 gün[14], Diyarbakır koşullarında ikinci ürün çeşitlerinde 60 -68 gün[9], Giresun koşullarına 10 Mayıs ekiminde 66-70 gün[15], Çukurova koşullarında birinci ürün yetiştirme sezonunda 68-71 gün[16], Tokat-Kozova koşullarında 63-83 gün arasında değişmiş olması, koçan püskülü çıkış süresinin varyetelere[17], ekim zamanlarına, iklim koşularına göre değiştiği bildirilmiştir. Bu nedenle mısır çeşitlerinin bölgelere göre ekim yapılırken tepe püskülü çıkış süresinin bilinmesi önem arz etmektedir. Ayrıca tepe püskülü çıkış süresinin sıcaklık stresinden korunması nedeniyle de bilinmesinde yarar vardır. 
Nevşehir Bilim ve Teknoloji Dergisi (2020), 9(2) 142-153

\section{2. $\quad$ Koçan Yüksekliği $(\mathrm{cm})$}

Araştırmada kullanılan hibrit mısır çeşitlerinin ilk koçan yüksekliği 53.7 (Performer) - 89.7 (Macha) cm arasında değiştiği, tüm çeşitlere ait ortalama koçan yüksekliği $70.3 \mathrm{~cm}$ olduğu tespit edilmiştir. Performer hibrit mısır çeşidi, P.32T83, Sancia, Tavascan, P.573, Calgary, Capuzi (62.6, 62.8, 64.8, 65.1, 66.6, 65.6 cm) hibrit mısır çeşitleri haricindeki çeşitlerden, istatistiki olarak koçan yüksekliği yönünden önemli farklılık oluşturmuştur. En yüksek koçan yüksekliği sahip Macha çeşidini $86.2 \mathrm{~cm}$ ile Simon çeşidi ve $83.9 \mathrm{~cm}$ ile Bolsan hibrit mısır çeşidi izlediği görülmüştür. Hydro, KB3961, Torra, KB5562 hibrit mısır çeşitleri aynı grubu oluşturdukları Bolsan, Simon, Macha, Performer çeşitleri arasında ise istatistiki olarak önemli farklılıkları oluşturdukları tespit edilmiştir. Motri, 72MAY80, PL712 hibrit mısır çeşitleri kendi aralarında istatistiki farklılık oluşturmayıp aynı grupta yer aldıkları kaydedilmiştir (Tablo 1). Yapılan çalışmalarda, ikinci ürün mısır bitkisinde koçan yüksekliği Kahramanmaraş koşullarında 63 - 94 cm[18], Kahramanmaraş koşullarında farklı gübre doz ve sıra üzeri uygulamasında 54.0-91.8 cm[19], Diyarbakır koşullarında $79.63-104.57 \mathrm{~cm}$ [20], Şanlıurfa koşullarında şeker mısırı çeşitlerinde $56.38-70.10 \mathrm{~cm}$ [21], Hatay koşullarında 103.5-126.7 cm[22], ön bitki ve yıllara göre $75-79 \mathrm{~cm}$ [23], 53 - $77 \mathrm{~cm}$ [13], Harran ovası koşullarında ilk yıl $83.75-121.75 \mathrm{~cm}$, ikinci yıl ise $88.75-134.25$ $\mathrm{cm}$ [24], birinci üründe ise Çukurova koşullarında farklı gübre uygulamalarında birinci üründe 96.33-137 cm[25], 98-140 cm[26], Samsun koşullarında 106.7-129.2 cm[27], Tokat-Kozova koşullarında 68.4-113.0 cm[17], Giresun koşullarında 110-153.3 cm[15], Çukurova koşullarında farklı çeşitlerde 97.7 - $123.9 \mathrm{~cm}$ [16], Konya, Bursa ve Sakarya bölgelerinde 36 genotipte 77.31-153.7 cm[28], Brezilya'da farklı gübre uygulamasında 62.25-78.00 cm[29] arasında değiştiği belirtilmiştir. Önceki çalışmalardan da görüldüğü gibi koçan yüksekliği çeşit karakteri olmasıyla birlikte ekim zamanlarına, bölgelere ve yapılan uygulama faktörlerine göre değişmektedir. Koçan yüksekliği hasat yüksekliği, depo organı olarak besinin taşınması yönünden önemlilik arz etmektedir.

\subsection{Koçan Uzunluğu (cm)}

İkinci ürün sezonunda denen hibrit mısır çeşitlerinin koçan uzunluğu 16.9 (Capuzi) - 22.2 (Calgary, Hydro) cm arasında değiştiği, tüm çeşitlerin ortalamasının $20.6 \mathrm{~cm}$ olduğu tespit edilmiştir. Araştırma sonunda koçan uzunluğu yönünden çeşitler birbirinden farklı altı grup oluşturduğu kaydedilmiştir. Koçan uzunluğunda Calgary, Hydro ve Simon hibrit mısır çeşitlerinin (22.2, 22.2 ve $22.1 \mathrm{~cm}$ ) aynı grupta yer aldığ kaydedilmiştir. PL712, Bolsan ve 72MAY80 hibrit mısır çeşitleri koçan uzunluğu sırasıyla 21.3,21.1,21.1 cm olup istatistiksel olarak başka bir grubu oluşturduğu tespit edilmiştir. Motri, P.32T83, hibrit mısır çeşitlerinin koçan uzunluğu sırasıyla 20.4, $20.3 \mathrm{~cm}$ olduğu istatistiksel olarak farklı bir grupta yer aldığı kaydedilmiştir. Performer hibrit mısır çeşidi $19.6 \mathrm{~cm}$ koçan uzunluğu ile ayrı bir grubu oluşturmuştur. Diğer Tavascan, Sancia, Torro Macha, KB5562, KB3961, P.573 (22.0, 21.5, 21.5, 20.0, 19.9, 19.6, 18.5 $\mathrm{cm}$ ) hibrit mısır çeşitleri koçan uzunluğu yönünden geçiş gruplarında yer aldığı belirlenmiştir (Tablo 1). Mısırla ilgili yapılan önceki çalışmalarda ana ürün mısırda koçan uzunluğunun Aydın koşullarında 17.3-19.5 cm[30], Çukurova koşullarında farklı yeşil ve çiftlik gübre uygulamasında 16.46-20.43 cm[25], Kahramanmaraş koşullarında ikinci ürün çeşitlerinde 17 - 26 cm(13), Çankırı koşullarında 18.27- $23.72 \mathrm{~mm}[26]$, Tokat-Kazova koşullarında farklı mısır çeşitlerinde 17.1-23.5 cm[17], Gümüşhane koşullarında farklı çeşitlerde 19.76-23 cm[15], Çukurova koşularında 17.9$20.6 \mathrm{~cm}$ [16], ikinci ürün mısırda ise koçan uzunluğunun 10.7-19.3 cm[19], Harran koşullarında şeker mısırında 17.25 $23.33 \mathrm{~cm}$ [21], Hatay koşullarında ikinci ürün çeşitlerinde 18.1-21.3 cm[22], Çukurova koşullarında 17.7-19.7 cm[31], Konya, Bursa ve Sakarya bölgelerinde 36 genotipde 13.4-20.6 cm[28], Brezilya'da farklı gübre uygulamasında 15.86$20.35 \mathrm{~cm}$ [29] arasında değiştiği belirtilmiştir. Birinci ürün koşularında 6 mısır çeşidi ile Diyarbakır koşullarında yürütülen çalışmada, koçan uzunluğu yönünden çeşitler arasında istatistiki olarak farkların olduğu ifade edilmiştir[32]. Koçan uzunluğu genetik özellik olmasına rağmen çevresel faktörlere göre değişkenlik gösterdiği önceki araştırıcıların bulgularından anlaşılmaktadır. Koçan uzunluğu verimi etkileyen ana unsurlardan biridir. Çeşitlerin koçan uzunluğunun 
Nevşehir Bilim ve Teknoloji Dergisi (2020), 9(2) 142-153

yetiştirildiği dönem (birinci veya ikinci ürün) ve bölgeye göre performansı farklılık göstermektedir, taze tüketim açısından koçan uzunluğu önemlilik arz etmektedir.

\subsection{Koçan Çapt (mm)}

Araştırmada kullanılan hibrit mısır çeşitlerinin koçan çapının 43.5 (P.32T83) - 49.5 (Torro) mm arasında değiştiği, tüm çeşitlerin ortalama koçan çapının 46.9 mm olduğu saptanmıştır. P.32T83 çeşidi, Motri ve P.573 (44.1 mm) hibrit mısır çeşitleri haricindeki çeşitlerden istatistiki olarak koçan çapı yönünden önemli farklılık oluşturmuştur. 72MAY80 ve PL712 hibrit mısır çeşitleri $(45.8,45.9 \mathrm{~mm})$, Capuzi çeşidi $(45.8 \mathrm{~mm})$ hariç, diğerlerinden farklı grupta yer aldığı belirlenmiştir. Torro çeşidi, Sancia $(49.2 \mathrm{~mm})$, Bolsan $(48.9 \mathrm{~mm})$, Tavascan (48.6 mm) ve Performer (48.6 mm) çeşitleri arasında istatistiki farklılık oluşturmaz iken, diğer çeşitlerden istatistiki olarak farklı olduğu tespit edilmiştir. Calgary, Hydro Simon, KB5562, KB3961 hibrit mısır çeşitleri koçan çapları sırasıyla 46.9, 46.9 48.2, 47.7, 47.6 mm olduğu ve istatistiki olarak bağlantılı geçiş gruplarında yer aldığı kaydedilmiştir (Tablo 1). Mısırla ilgili araştırıcıların yapmış oldukları çalışmalarda; mısır koçan çapının ana üründe Çukurova koşullarında 36.33 - 44.00 mm[25], Konya koşullarında 52.08 - 52.85 mm[33], Bornova ve Ödemiş koşullarında 4 çeşitte 4.63-4.82 cm[34], Orta Kızılırmak havzasında 46.63- $51.85 \mathrm{~mm}$ [26], Gümüşhane koşullarında farklı çeşitlerde 45.33-48.86 mm[15], Çukurova koşullarında farklı çeşitlerde 43.6- 49.5 mm[16], ikinci ürün koşullarında ise Diyarbakır koşullarında 45.27-50.50 mm[20], Hatay koşullarında 44.2-49.7 mm[22] arasında değiştiği belirtilmiştir. Diyarbakır koşullarında birinci ürün olarak 6 mısır çeşidi ile yapılan araştırmada, çeşitler arasında koçan çapı yönünden istatistiksel olarak farkların önemli olduğu kaydedilmiştir[32]. Koçan çapı tanenin büyüklüğünü ifade eden bir özellik olmasından dolayı çeşitlere göre değişmekle birlikte çevresel faktörlerden çok etkilenen özelliktir. Yapılan araştırma sonuçları da bu durumu ifade etmektedir.

\subsection{Koçanda Stra Sayısı (adet)}

Hibrit mısır çeşitlerinin ikinci ürün sezonunda koçanda sıra sayısının 14.5 (Hydro ve 72MAY80) - 16.9 (PL712 ve Bolsan) adet arasında değiştiği, çeşitlerin ortalamasının 15.2 adet olduğu belirlenmiştir. KB5562, Motri, P.573, Sancia, KB3961, Performer, Torro, Calgary, Simon, Capuzi, Macha, P.32T83, Tavascan hibrit mısır çeşitleri sırasıyla 14.9, 15.3 15.3, 15.5, 15.5, 15.7, 16.0, 16.0 16.0, 16.1, 16.1, 16.5, 16.8 adet koçanda sıra sayısı değeri sahip olduğu ve geçiş gruplarında yer aldığı belirlenmiştir (Tablo 1). Mısır bitki üzerinde daha önce yapılan çalışmalarda koçanda sıra sayısının Karadeniz koşullarında yerel çeşitlerde 8.00 - 20.18 adet[35], Kahramanmaraş koşullarında cin mısırı genotipde 14.6617.5 adet[12], Alaşehir-Manisa koşullarında 4 faklı ekim ve 4 çeşitte 10.0-17.8 adet[36], İzmir koşullarında 13.7-14.4 adet[34], Giresun koşullarında 14.8-18.13 adet[15], Konya, Bursa ve Sakarya bölgelerinde 36 genotipde 13.3-20.3 adet[28], Brezilya'da farklı gübre uygulamasında 13.87-15.25 adet[29] arasında değiştiği kaydedilmiştir. Koçanda sıra sayısına çeşit özeliğinin etkisi çevresel faktörlerden daha baskındır, verimi belirlemede etkili olduğu gibi taze tüketim için kullanımda da öne çıkan özelliklerden olması nedeniyle, çeşitlere ait koçanda sıra sayısının bilinmesinde yarar vardır[37ve 38].

\subsection{Koçan Strasında Tane Sayısı (adet)}

İkinci ürün olarak yetiştirilen 17 hibrit mısır çeşidinin koçan sırasında tane sayısının 31.6 (P.573) - 45.0 (Simon) adet arasında değiştiği, tüm çeşitlerin ortalamasını ise 39.6 adet olduğu kaydedilmiştir. P.573 çeşidi Capuzi hibrit mısır çeşidi (34.3 adet) haricindeki diğer çeşitlerden istatistiki olarak önemli farklılık oluşturmuştur. Tavascan, Motri, 72MAY80, Macha, PL712, Torro hibrit çeşitleri (40.5, 38.9, 40.2, 38.7, 39.3, 38.9 adet) sahip oldukları koçan sırasında tane sayısı ile aynı geçiş grubunda yer aldığı kaydedilmiştir. P.32T83, Performer, KB 5562 çeşitleri (38.3, 38.1, 37.2 adet) sahip oldukları kaçan sırasında tane sayısı ile bağlantılı geçiş gruplarında yer almışlardır. Simon çeşidi ile KB 3961 (44.9 
Nevşehir Bilim ve Teknoloji Dergisi (2020), 9(2) 142-153

adet/koçan) çeşitleri aynı grupta yer almıştır. Simon ve KB3961 hibrit mısır çeşitleri koçan sırasında tane sayısı yönünden Blosan, Calgary, Sancia, Hydro (42.9, 42.1, 41.9, 41.1 adet) çeşitleri ile aralarında istatistiki olarak önemli farklılık oluşturmamıştır (Tablo 1). Koçan sırasında tane sayısını cin mısırı genotipde 28.56-37.66 adet[12], 32.73-37.4 adet[15], Konya, Bursa ve Sakarya bölgelerinde 36 genotiple 35.3-47.0 adet[28], Brezilya'da 40.16-42.08 adet[29] arasında değiştiği belirtilmiştir. Koçan sırasında tane sayısı, çeşit özelliği olmasıyla birlikte çevresel faktörlerden en fazla etkilenen bir özelliktir [37 ve 38]. Bu nedenle çevresel faktörlere göre değişimi çok hızlıdır.

\subsection{Koçanda Tane Ăğırlı̆̆ (g)}

Kahramanmaraş koşullarında ikinci ürün olarak yetiştirilen 17 hibrit mısır çeşidinin koçan tane ağırlıkları 114.8 (P.573) - 219.6 (Simon) g arasında değiştiği, çeşitlerin ortalaması ise 184.5 g olduğu tespit edilmiştir. Koçan tane ağırlığında P.32T83 çeşidi (146.8 g) ve Macha (151.8 g) çeşitleri diğer çeşitlerden istatistiki olarak farklılık oluşturduğu kaydedilmiştir. Sancia, Hydro, PL712 (200.5, 200.8, 200.8 g) çeşitleri tek koçanda tane ağırlığı yönünde aynı grupta yer almıştır. Calgary ve Performer (181.8, 182.7 g) hibrit mısır çeşitlerinin tek koçanda tane ağırlığı yönünden KB5562 (180.4 g) çeşidi ile aralarında istatistiki olarak fark oluşturmaz iken, diğer çeşitler ile aralarında istatistiki olarak önemli farklılık gösterdiği belirlenmiştir. Simon çeşidi ile Tavascan, Bolsan (214.8, $215.3 \mathrm{~g})$ çeşitleri arasında istatistiki olarak önemli farklılık oluşmadığı tespit edilmiştir. Torro, 72MAY80, KB3961, Motri, Capuzi hibrit mısır çeşitlerinin koçanda tane ağırlığının sırasıyla 202.7, 195.7, 191.0, 173.1, 164.6 g olduğu ve geçiş gruplarını oluşturduğu kaydedilmiştir(Tablo 2). Mısır bitkisi ile yapılan çalışmalarda; tek koçanda tane ağırlığını ikinci üründe Diyarbakır koşullarında farklı çeşitlerde 159.33-206.00 g[20], farklı azot gübre uygulamasında 152-255 g[8], Kahramanmaraş koşullarında farklı çeşit denemesinde 177-311 g[13], Şanlıurfa koşullarında farklı çeşitlerde 225.70-279 g[39], ana üründe ise Şanlıurfa koşullarında 116.8-149.1 g[40], cin mısırı genotiplerinde 48.8-66.0 g[12], yerel mısır çeşitlerinde 23.54-186.86 g[35], Bursa koşullarında farklı melez gruplarında 214.48-272.37 g[41] arasında değiştiği belirtilmiştir. Koçan tane ağırlığı çeşit özelliği olmakla birlikte, çevresel faktörlerden daha fazla etkilendiği yapılan önceki çalışma sonuçlarda bu durumu açıklamaktadır.

Tablo 2. İkinci ürün hibrit mısır çeşitlerinin koçan tane ağırlığı, tane oranı, bin tane ağırlığı, protein, nişasta ve yağ oranlarına ait ortalamalar ve grupları

\begin{tabular}{|c|c|c|c|c|c|c|}
\hline Çeşitler & $\begin{array}{l}\text { Koçanın Tane } \\
\text { Ağırlığ } 1(\mathrm{~g})^{* *}\end{array}$ & Tane Oranı $(\%)^{* *}$ & $\begin{array}{l}\text { Bin Tane } \\
\text { A } \breve{g} 1 r l{ }_{1} \breve{g}_{1}(\mathrm{~g}) * *\end{array}$ & $\begin{array}{l}\text { Protein } \\
\text { Oran1 }(\%)^{* *}\end{array}$ & $\begin{array}{l}\text { Nişasta } \\
\text { Oranı(\%)** }\end{array}$ & Yağ Oranı(\%)** \\
\hline Tavascan & $214.8 \mathrm{ab}$ & $85.6 \mathrm{def}$ & $372.1 \mathrm{ab}$ & $9.5 \mathrm{a}$ & $66.1 \mathrm{gh}$ & $3.4 \mathrm{abc}$ \\
\hline Motri & $173.1 \mathrm{gf}$ & $88.8 \mathrm{a}$ & $335.9 \mathrm{~d}$ & 8.6 cde & $67.6 \mathrm{def}$ & $3.2 \mathrm{a}-\mathrm{d}$ \\
\hline Calgary & $181.8 \mathrm{def}$ & $85.6 \mathrm{def}$ & $338.3 \mathrm{~cd}$ & $7.8 \mathrm{gh}$ & $67.7 c-f$ & 3.0 a-e \\
\hline Sancia & $200.5 \mathrm{c}$ & 85.1 ef & $346.8 \mathrm{~cd}$ & $8.0 \mathrm{fgh}$ & $68.6 \mathrm{a}-\mathrm{d}$ & $2.4 \mathrm{~g}$ \\
\hline P.573 & $114.8 \mathrm{j}$ & $84.3 \mathrm{f}$ & $313.4 \mathrm{e}$ & $7.6 \mathrm{~h}$ & $69.6 \mathrm{a}$ & $2.4 \mathrm{fg}$ \\
\hline P.32T83 & 146.81 & 86.4 cde & $283.3 \mathrm{f}$ & $8.1 \mathrm{fgh}$ & 67.4 ef & $3.2 \mathrm{a}-\mathrm{d}$ \\
\hline Hydro & $200.8 \mathrm{c}$ & $88.2 \mathrm{ab}$ & $369.5 \mathrm{~b}$ & $7.6 \mathrm{~h}$ & $68.1 \mathrm{~b}-\mathrm{e}$ & $2.5 \mathrm{efg}$ \\
\hline Performer & $182.7 \mathrm{def}$ & 86.4 cde & $343.6 \mathrm{~cd}$ & $7.8 \mathrm{~h}$ & $68.1 \mathrm{~b}-\mathrm{e}$ & $2.7 \mathrm{~d}-\mathrm{g}$ \\
\hline Capuzi & $164.6 \mathrm{gh}$ & 87.4 bc & $311.9 \mathrm{e}$ & $8.0 \mathrm{fgh}$ & $68.8 \mathrm{abc}$ & $3.3 \mathrm{abc}$ \\
\hline 72May80 & $195.7 \mathrm{~cd}$ & $86.6 \mathrm{~cd}$ & $381.8 \mathrm{ab}$ & $9.3 \mathrm{ab}$ & $67.4 \mathrm{def}$ & $2.8 \mathrm{~d}-\mathrm{fg}$ \\
\hline Simon & $219.6 \mathrm{a}$ & $88.3 \mathrm{ab}$ & $383.9 \mathrm{a}$ & $8.9 \mathrm{bcd}$ & $66.7 \mathrm{fg}$ & $3.2 \mathrm{a}-\mathrm{d}$ \\
\hline Macha & $151.8 \mathrm{~h} 1$ & $84.2 \mathrm{f}$ & $274.0 \mathrm{f}$ & 8.7 cde & $68.1 \mathrm{~b}-\mathrm{e}$ & $3.5 \mathrm{a}$ \\
\hline PL712 & $200.8 \mathrm{c}$ & $84.1 \mathrm{f}$ & $337.3 \mathrm{~d}$ & $9.1 \mathrm{abc}$ & $67.2 \mathrm{efg}$ & $2.7 \mathrm{~d}-\mathrm{g}$ \\
\hline Torro & $202.7 \mathrm{bc}$ & 86.4 cde & $355.5 \mathrm{c}$ & $9.2 \mathrm{ab}$ & $66.6 \mathrm{fgh}$ & $3.0 \mathrm{~b}-\mathrm{f}$ \\
\hline Bolsan & $215.3 \mathrm{ab}$ & 86.4 cde & $353.6 \mathrm{c}$ & $9.6 \mathrm{a}$ & $65.5 \mathrm{~h}$ & $3.4 \mathrm{ab}$ \\
\hline KB 5562 & 180.4 ef & $84.9 \mathrm{f}$ & $371.2 \mathrm{ab}$ & $8.7 \mathrm{def}$ & $67.1 \mathrm{efg}$ & $2.7 \mathrm{~d}-\mathrm{g}$ \\
\hline \multirow[t]{2}{*}{ KB 3961} & $191.0 \mathrm{cde}$ & $89.5 \mathrm{a}$ & $312.5 \mathrm{e}$ & $8.3 \mathrm{efg}$ & $69.3 \mathrm{ab}$ & $2.9 \mathrm{c}-\mathrm{g}$ \\
\hline & 184.5 & 86.4 & 340.3 & 8.5 & 67.6 & 3.0 \\
\hline
\end{tabular}

** $(\leq 0.01), *$ Her sütunda aynı harfle gösterilen ortalamalar arasında 0.01 önem düzeyine göre fark yoktur.

\subsection{Tane Oranı (\%)}

İkinci ürün sezonunda yetiştirilen hibrit mısır çeşitlerinin koçanda tane oranları \%84.1 (PL 712) - 89.5 (KB 3961) arasında değiştiği, çeşitlerin ortalaması ise \%86.4 olduğu kaydedilmiştir. PL 712, Macha, P.573, KB5562 hibrid mısır çeşitlerinde aynı grupta yer aldığı kaydedilmiştir. KB 3961 ve Motri çeşitleri ile Simon ve Hydro çeşitleri arasında 
Nevşehir Bilim ve Teknoloji Dergisi (2020), 9(2) 142-153

istatistiki olarak önemli farklılığın bulunmadığı, fakat diğer çeşitler ile aralarında istatistiki olarak önemli farklılığın olduğu tespit edilmiştir. Sancia, Calgary, Tavascan (\%85.1, \%85.6, \%85.6) hibrit mısır çeşitleri istatistiki olarak kendi aralarında önemli farklılık oluşturmayıp geçiş grubunda yer almışlardır. P.32T83, Performer, Torro, Bolsan çeşitleri (\% 86.4), 72MAY80, Capuzi hibrid mısır çeşitleri (\%87.4) bağlantılı geçiş gruplarında yer aldığı kaydedilmiştir(Tablo 2). Ana ürün mısırda tane oranını Samsun ve Bafra koşullarında 27 çeşitte \%77.0 -84.0[42], Karadeniz koşularında yerel çeşitlerinde \%69.82-86.92[35], farklı melez gruplarında \%84.21-86.68[41], Samsun koşullarında \%80.7-88.3[43], Samsun koşullarında 20 genotipde \% 77.4-85.4[27], Diyarbakır koşullarında \%83.63-88.00[9], ikinci üründe ise Diyarbakır ve Şanlıurfa koşullarında \%76.55-81.93[40], Şanlıurfa koşularında \%77.79 - 81.53[44], ilk yıl \% 80.2587.75[24], ikinci yıl \%78.75, Diyarbakır koşullarında \%79.1-84.0[9], Şanlıurfa koşullarında ikinci ürün koşullarında \%77-91[39] arasında değiştiği belirtilmiştir. Diyarbakır koşullarında birinci ürün mısır çeşitleri arasında tane oranı yönünden önemli farklar olduğunu ve çeşitlere göre değiştiği kaydedilmiştir[32]. Tane oranı çeşit karakterleri yanı sıra çevresel faktörlerden etkilenmektedir. Daha önce yapılan araştırma sonuçları da bu durumu göstermektedir. Önceki araştırıcıların sonuçlarında elde edilen değerlerle ile bulgularımız paralellik göstermiş̧ir.

\subsection{Bin Tane A Ăgrllğı (g)}

Hibrit mısır çeşitlerinin ikinci ürün yetişme sezonunda bin tane ağırlıkları 274.0 (Macha) - 383.9 (Simon) g arasında değiştiği, çeşitlerin ortalaması ise $340.3 \mathrm{~g}$ olduğu kaydedilmiştir. Bin tane ağırlığı yönünden Simon çeşidi ile 72MAY80, Tavascan ve KB5562 çeşitleri, Macha ile P.32T83 çeşitleri, Torro ile Bolsan çeşitleri, Motri ile PL712 çeşitleri, P.573 ile Capuzi ve KB3961 çeşitleri, Hydro çeşidi birbirlerinden istatistiki olarak farklı altı grup oluşturduğu kaydedilmiştir (Tablo 2). Ana ürün mısırda bin tane ağırlığını Aydın koşullarında 10 mısır çeşidinde 243-330 g[30], Orta Kızılırmak havzası koşularında 287-354 g[26], Tokat koşullarında 330-436 g[17], Gümüşhane koşullarında 184.6-249.04 g[15], Ege bölgesi koşullarında 302.7-365.7 g[45], Çukurova koşullarında 280.6-345.9 g[16], Konya, Bursa ve Sakarya bölgelerinde 36 genotipde 238.0-394 g[28], Çukurova koşularında ikinci üründe farklı azot ve çeşitlerde 297.8-366.5 g[31], farklı azot gübre uygulamasında 321-378 g[8], ön bitkiye ve yıllara göre 345-353 g[23], Diyarbakır koşullarında ana ve ikinci ürüne göre 336.1-444.0 g[9], Brezilya'da 293.5-336.6 g[29] arasında değiştiği belirlenmiştir. Bin tane ağırlığı çeşit özeliği, iklim, toprak, ekim zamanı gibi koşullardan etkilenen bir özelliktir. Çeşitlere ait bin tane ağırlığının bilinmesi, ekimde kullanılacak tohumluk miktarı ve ekim derinliği, dekara verim hesaplama, sanayinde kullanım alanı gibi unsurlara yardımcı olacaktır.

\subsection{Tanede Protein Oranu (\%)}

Araştırmada kullanılan hibrit mısır çeşitlerinin tanede protein oranı \%7.6 (Hydro) - 9.6 (Bolsan) arasında değiştiği, çeşitlerin ortalaması ise \%8.5 olduğu görülmüştür. Bolsan ve Tavascan çeşitleri tanede protein oranı yönünden 72MAY80, Torro, PL712 hibrid mısır çeşitleri dışındaki çeşitlerden önemli derecede farklı oldukları tespit edilmiştir. Hydro, P.573, Performer hibrid mısır çeşitleri, Calgary, Sancia, P.32T83, Capuzi hibrid mısır çeşitleri dışındaki çeşitlerden tanede protein oranı yönünden önemli farkl1lık oluştuğu görülmüştür. Motri, Simon, Macha, KB5562, KB3961 hibrit mısır çeşitlerinde tanede protein oranının yönünden geçiş gruplarında yer aldığı belirlenmiştir (Tablo 2). Mısır tanesindeki protein oranını su stres uygulamasında \% 6.59- 8.16[46], ikinci üründe ön bitkiye ve yıllara göre \% 7.949.15[23],Karadeniz koşullarında \% 8.88-16.42[35], Samsun koşullarında ana üründe \% 10.14-10.69[27], kaliteli proteinli mısırda \%9.72[47], farklı çinko uygulamasında \% 6.1-7.9[48], Ege bölgesi koşullarında \% 6.18- 7.84[45], üç mısır çeşidinde \%8.50-10.49[49], Diyarbakır'da ana ve ikinci ürün koşullarında \% 8.3-10.2[9], İzmir koşullarında farklı çeşitlerde \% 6.19 to 8.39[50], farklı lokasyonlarda \%6.9-7.8[51], Konya, Bursa ve Sakarya bölgelerinde 36 genotipde \% 6.41-9.43[28], Şanlıurfa koşullarında ikinci üründe \%7.67-14.50[39] arasında değiştiği bildirilmiştir. Mısır bitkisinde 
Nevşehir Bilim ve Teknoloji Dergisi (2020), 9(2) 142-153

protein oranı çeşide bağlı bir özellik olmakla birlikte, iklim koşulları ve yetişme dönemindeki çevresel koşullardan etkilenmektedir. Çeşitlere ait protein değerinin, insan ve hayvan beslenmesinin yanı sıra sanayi kullanımında dikkate değer bir özellik olduğundan, bilinmesi oldukça önemlidir.

\subsection{Tanede Nişasta Oranı (\%)}

İkinci ürün olarak yetiştirilen 17 hibrit mısır çeşidinin tanedeki nişasta oranları \%65.5 (Bolsan) - 69.6 (P. 573) arasında değiştiği, çeşitlerin ortalaması ise \%67.6 olduğu belirlenmiş̧ir. P.573 çeşidi ile KB3961, Capuzi, Sancia hibrit mısır çeşitleri arasında istatistiki olarak önemli farklılığın olmadığı, diğer çeşitler ile arasında istatistiksel olarak önemli farklılıkların olduğu kaydedilmiştir. Bolsan çeşidi ile Tavascan, Torro çeşitleri arasında tanede nişasta oranı yönünden istatistiksel olarak önemli farklılığın olmadığı, fakat diğer çeşitler arasında önemli farklılığın oluş̧uğu belirlenmiştir. Motri, Calgary, P.32T83, 72MAY80, PL712, KB5562, Simon hibrit mısır çeşitleri tanede nişasta oranı yönünden geçiş gruplarında yer aldığı kaydedilmiştir. Hydro, Performer ve Macha mısır çeşitleri tanede nişasta oranı açısından istatistiksel olarak aynı geçiş grubunda yer aldıkları tespit edilmişsir (Tablo 2). Nişasta oranının ana ürün mısır bitkisinde \%58.33-67[46], Karadeniz koşullarında \%63.00-73.64[35], farklı çinko uygulamasında \%60.8- 64.2[48], Diyarbakır koşullarında ana ve ikinci üründe \%71.51 - 72.95[9], ikinci üründe \%61.74-63.28[45], normal mısırda \%69, mumlu mısırda \%72, süper tatlı mısırda \%30[52], ikinci ürün çeşitlerinde \%73.2-73.9[14], farklı lokasyonlarda \%62.663.9[51], Konya, Bursa ve Sakarya bölgelerinde 36 genotipde \%57.1-61.5[28], Şanlıurfa koşullarında ikinci ürün koşullarında \%58.73-76.30[39] arasında değiştiği belirtilmiştir. Diyarbakır koşullarında nişasta oranı yönünden birinci ürün çeşitleri arasında istatistiki önemli farkların olduğu kaydedilmiştir[32]. Tanede nişasta oranı üzerine; çeşit, yağış, sıcaklık, toprak tipi ve gelişme koşuları genetik koşullarından daha fazla etkili olabilmektedir[53 ve 54]. Tane dolum esnasındaki düşük ışık stresinin nişasta oluşumunu etkilediği belirtmiştir [55]. Yapılan daha önceki çalışmalardan da tane nişasta oranının çevresel faktörlere göre farklılık göstereceği anlaşılmaktadır. Sanayide önemli yere sahip olan mısır, nişasta oranının bilinmesi kulanım alanlarında farklılık oluşturmaktadır.

\subsection{Tanede Yă̆ Oranı (\%)}

Araştırmada ikinci ürün yetiştirilme sezonunda kullanılan 17 hibrit mısır çeşidinin yağ oranları \%2.4 (Sancia) 3.5 (Macha) arasında değiştiği, çeşitlerin ortalaması ise \%3.0 olduğu belirlenmiştir. Macha çeşidi tanede yağ oranı yönünden Bolsan, Tavascan, Motri, Calgary, P.32T83, Capuzi, Simon hibrit mısır çeşitleri haricindeki, diğer çeşitlerden istatistiksel olarak farkl11ık gösterdiği kaydedilmiştir. Sancia çeşidi ile P.573, Hydro, Performer, 72MAY80, PL 712, KB5562, KB3961 hibrit mısır çeşitleri arasında istatistiksel olarak farklılı̆̆ın olmadığı, diğer çeşitler ile arasında istatistiki önemli farklılı̆̆ın olduğu belirlenmiştir. P.573, Hydro, Performer, 72MAY80, PL712, KB5562, KB3961, Torro, Bolsan, Tavascan, Motri, Calgary, P.32T83, Capuzi, Simon hibrit mısır çeşitleri geçiş gruplarında yer almışlardır (Tablo 2). Mısır tanesindeki yağ oranları ile yapılan çalışmalarda; farklı su stres koşullarında \%2.39-3.92[46], Karadeniz koşullarında farklı çeşitlerde \%2.22-6.41[35], Samsun koşullarında ana üründe \%4.12-4.76[27], kaliteli protein mısırında \%4.85[47], farklı çinko doz uygulamasında \%2.7-3.3[48], üç mısır çeşidinin \%2.86-3.84[49], Diyarbakır koşullarında ikinci üründe \%3.0-4.6[9], farklı lokasyonlardaki genotiplerde \%2.88-3.80[28], Şanlıurfa koşullarında farklı mısır çeşitlerinde \%3.10-8.27[39] arasında değiştiği kaydetmiş̧tir. Kılınç ve ark. (2018) ham yağ oranı yönünden çeşitler arasında önemli farklılıkların olduğunu belirtmişlerdir [32]. Mısır bitkisinde yağ oranları çevresel faktörlerden etkilenmekte birlikte genetik faktörlerin etkisi daha baskındır. Önceki çalışmalarda elde edilen sonuçlardan da görüleceği gibi araştırmada kullanılan çeşitlerin yağ oranlarının düşük olduğu anlaşılmaktadır. 
Nevşehir Bilim ve Teknoloji Dergisi (2020), 9(2) 142-153

\section{Sonuc}

Mısır bitkisinin tanesi bir tahıl olarak değerlendirilmekle birlikte, son yıllarda sanayide kullanımının hızla artması nedeniyle endüstri bitkisi olarak kullanımı yaygınlaşmaktadır. Sanayinde yaygın olarak un, nişasta, yem, yağ gibi ürünlerin eldesin de kullanılmaktadır. Bir yıllık araştırma sonucuna göre, kullanılan hibrit mısır çeşitlerinin yağ oranlarının düşük olmasından dolayı yağlık çeşit olarak öneride bulunulmamaktadır. Yine bir y1llık değerlendirmeye göre; koçan püskülü çıkış süresinin 52-59 gün arasında olması ve hasat olgunluğunun 100-115 arasında gerçekleşeceği varsayımından, tüm çeşitlerin ikinci ürün olarak Akdeniz ve Güneydoğu Anadolu bölgelerine önerilmektedir. Tüm çeşitlerde elde edilen değerler dikkate alındığında protein yönünden Bolsan, Tavascan, 72MAY80, Torro, PL712 hibrid mısır çeşitlerinin, nişasta yönünden P.573, KB3961, Capuzi ve Sancia çeşitlerinin, taze tüketim için uzun koçanlıların tercih edileceğinden Calgary, Hydro ve Simon çeşitlerinin önerilmesi uygun görülmüştür

\section{Teșekkür}

Bu araştırma, 2016/5-45 YLS nolu, yüksek lisans projesi olarak Kahramanmaraş Sütçü İmam Üniversitesi, Bilimsel Araştırma Birimi tarafından desteklenmiş olup, desteklerinden dolayı teşekkür ederiz.

\section{Kaynaklar}

[1] Anonim, Foastat, 2020

[2] Anonim, Türkiye İstatistik Kurumu, Tarım İstatistik. 2020.

[3] Manoj K., Ghimire S. K., Ojha B. R., Shrestha J. "Genetic Diversity for Heat Tolerant Related Traits in Maize Inbred Lines”, Agricultura, 105(1-2), Journal ISSN: Print ISSN 1221-5317. 2018.

[4] Becher D. "Effect of Population Density Changes and Ear Style on Kernel Size and Yield in Grain Corn" Iowa State University, Master of Science, Lowa, 25p, 2018.

[5] Liangfa W., Jinhua Y., Jinkui Z., Sujuan Z., Ruiqian L. "Activity of Corn Silk at Different Days after Silk Emergence" Agricultural Science \& Technology, Changsha, 18(12) 2212-2218. 2017.

[6] Tiryaki N. Ö., Irmak S. Evaluation of Various Corn Variety Kernels for Hydrogen Gas Production by APR. Biomass and Bioenergy. 134. https://doi.org/10.1016/j.biombioe.2020.105480, 2020.

[7] Lara S. G., Hernandez C. C., Saldivar S. O. S. "Development and Structure of the Corn Kernel" Chapter 6. Chemistry and Technology. P.147-163 Corn Book - 3rd Edition. Edited by: Sergio O. Serna-Saldivar. https://doi.org/10.1016/B978-0-12-811971-6.00006-1. 2019.

[8] Idikut L., Tiryaki I., Tosun S., Celep H. "Nitrogen Rate and Previous Crop Effects on Some Agronomic Traits of Two Corn (Zea mays L.) Cultivars Maverik and Bora" African Journal of Biotechnology, 8(19): 4958-4963, 2009.

[9] Kahraman Ş. "Diyarbakır koşullarında ana ve ikinci ürün tane mısır tarımında bazı tarımsal ve teknolojik özellikler üzerine araştırmalar” Dicle Üniversitesi, Fen Bilimleri Enstitüsü, Tarla Bitkileri Anabilim Dall, Doktora Tezi, Diyarbakır, 151s, 2016.

[10] Anonim, Doğu Akdeniz Geçit Kuşağı Tarımsal Araştırma Enstitüsü Müdürlüğü, Toprak Loboratuarı. Kahramanmaraş. 2016

[11] Anonim, Kahramanmaraş Meteoroloji İstasyon Müdürlüğü. Kahramanmaraş. 2016.

[12] İdikut L., Yılmaz A., Yürürdurmaz C., Çölkesen M. "Yerel Cin Mısırı Genotiplerinin Morfolojik Ve Tarımsal Özelliklerinin Belirlenmesi” Biyoloji Bilimleri Araştırma Dergisi 5 (2): 63-69, 2012. 
Nevşehir Bilim ve Teknoloji Dergisi (2020), 9(2) 142-153

[13] İdikut L., Kara S. N., “Tane Ürünü İçin Yetiştirilen İkinci Ürün Mısır Çeşitlerinin Bazı Verim Öğeleri ile Tane Nişasta Oranlarının Belirlenmesi” Kahramanmaraş Sütçü İmam Üniversitesi Doğa Bilimleri Dergisi, 16(1), 8$15,2013$.

[14] İdikut L., Zulkadir G., Yürürdurmaz C., Çölkesen M. "Yerel Cin Mısırı Genotiplerinin Kahramanmaraş Koşullarında Tarımsal Özelliklerinin Araştıılması” Kahramanmaraş Sütçü İmam Üniversitesi Doğa Bilimleri Dergisi, 18(3):1-8. 2015.

[15] Han E. "Bazı mısır çeşitlerinin dane verimleri ile silaj ve kalite özelliklerinin belirlenmesi” Ordu Üniversitesi, Fen Bilimleri Enstitüsü Tarla Bitkileri Anabilim Dalı, Yüksek Lisans Tezi, Ordu, 65s, 2016.

[16] Saygı M., Toklu F. “Çukurova Bölgesinde Birinci Ürün Koşullarında Yetiştirilen Bazı Danelik Mısır (Zea mays indentata Sturt.) Çeşitlerinin Dane Verimi, Bazı Bitkisel Özellikler ve Karakterler Arası İlişkiler Yönünden Değerlendirilmesi” Kahramanmaraş Sütçü İmam Üniversitesi Tarım ve Doğa Bilimleri Dergisi, 20 (Özel Say1), 308-312. doi: 10.18016/ksudobil.349269. 2017.

[17] Çakar Ş. "Bazı atdişi hibrit mısır (Zea mays indentata L.) çeşitlerinin Tokat Kozova koşullarında performanlarının belirlenmesi. Gaziosmanpaşa Üniversitezi, Fen Bilimleri Enstitüsü Tarla Bitkileri Anabilim Dal, Yüksek Lisans Tezi, Tokat.45s. 2015.

[18] Cesurer, L. "Kahramanmaraş koşullarında ana ürün olarak yetiştirilebilecek yüksek verimli melez mısır çesitleri üzerinde araştırmalar” Tarla Bitkileri Kongresi, Cilt: 1, s 267 - 270, İzmir, 1994.

[19] Alııı S., "Kahramanmaraş Koşullarında Farklı Azot Dozları İle Sıra üzeri Ekim Mesafelerinin II. Ürün Mısır Bitkisinde Verim, Verim Unsurları ve Bazı Tarımsal Karakterlere Etkisi Üzerine Bir Araştırma" Çukurova Üniversitesi, Fen Bilimleri Enstitüsü, Tarla Bitkileri Ana Bilim Dalı Doktora Tezi, Adana.137s. 2005.

[20] Sarikurt B., Bengisu G. "Diyarbakır Sulu Koşullarında II. Ürün Olarak Yetiştirilen Bazı Mısır Çeşitlerinde Verim ve Bazı Tarımsal Karakterler ile Karakterler Arası İlişkilerin Belirlenmesi. Avrupa Bilim ve Teknoloji Dergisi, 18, 243-247. https://doi.org/10.31590/ejosat.681220. 2020.

[21] Öktem A., Öktem A. G. "Bazı şeker mısır (Zea mays saccharata sturt.) Genotiplerinin Harran Ovası Kosullarında Verim Karakteristiklerinin Belirlenmesi” Uludag Üniversitesi Ziraat Fakültesi Dergisi, 20(1) : 33-46, 2006.

[22] Gözübenli H., Ülger A. C., Kılınç M., Şener O., Karadavut U. "Hatay koşullarında ikinci ürün tarımına uygun mısır çeşitlerinin belirlenmesi” Türkiye II. Tarla Bitkileri Kongresi, 22 - 25 Eylül 1997 Samsun, s: 153 - 157. 2007.

[23] İdikut L., Kara S. N. "The Effects of Previous Plants and Nitrogen Rates on Second Crop Corn" Turkish Journal of Field Crops, 16(2): 239-244 doi: 10.4314/ajb.v8i19.65199. 2011.

[24] Coşkun Y., Coşkun A., Koşar İ. "Bazı At Dişi Mısır Çeşitlerinin Harran Ovası İkinci Ürün Koşullarına Adaptasyonu” Türk Tarım ve Doğa Bilimleri Dergisi 1(4): 454-461. 2014.

[25] Gürses M. A. "Mısır Yetiştiriciliğinde Değişik Yeşil Gübre Bitkileri ve Çifflik Gübresi Uygulamalarının Verim ve Verim Unsurlarına Etkisi. Çukurova Üniversitesi, Fen Bilimleri Enstitüsü, Tarla Bitkileri Anabilim Dall, Yüksek Lisans Tezi, Adana, 89s, 2010.

[26] Kuşvuran A., Nazlı R.İ. “Orta kızılırmak havzası ekolojik koşullarında bazı mısır (Zea mays L.) çeşitlerinin tane mısır özelliklerinin belirlenmesi” Yüzüncü Yıl Üniversitesi Tarım Bilimleri Dergisi, 24(3),233-240. 2014.

[27] Özata E., Öz A. “Atdişi Hibrit Mısır Adaylarının Ana Ürün Koşullarında Verim ve Kalite Özelliklerinin Belirlenmesi" Tartm Bilimleri Araşttrma Dergisi, 7 (1): 06-11. ISSN: 1308-3945, E-ISSN: 1308-027X, www.nobel.gen.tr. 2014. 
Nevşehir Bilim ve Teknoloji Dergisi (2020), 9(2) 142-153

[28] Doğanlar C. "Farklı Lokasyonlarda Yetiştirilen Bazı Melez Mısır Çeşit Adaylarının Verim ve Verim Öğelerinin Belirlenmesi” Uludağ Üniversitesi, Fen Bilimleri Enstitüsü, Yüksek Lisans Tezi, S 100, 2018.

[29] Bueno D. S. Lima S. F., "Blanco M., Coradi P. C. Management of Nitrogen Fertilization On Agronomic and Nutritional Characteristics in Second Crop Corn" Bioscience Journal, 36 (2): 439-448. http://dx.doi.org/10.14393/BJ-v36n2a2020-45166. 2020.

[30] Koça Y.O., Erekul O. "Bazı Melez Mısır Çeşitlerinin Performanslarının Belirlenmesi". Adnan Menderes Üniversitesi Ziraat Dergisi, 8(2) : 41 - 45. 2011.

[31] Türkay M. A., Cerit İ., Sarıhan H., Şen H. M. Çınar S., Ülger A.C. "Farklı azot dozlarının at dişi melez mısır çeşitlerinde tane verimi ve bazı tarımsal özelliklere etkisi” VII. Tarla Bitkileri Kongresi, 1, 84-87. Erzurum. 2007.

[32] Kılınç S., Karademir Ç., Ekin Z. Bazı Mısır (Zea mays L.) Çeşitlerinde Verim ve Kalite Özelliklerinin Belirlenmesi. Kahramanmaraş Sütçü İmam Üniversitesi Tarım ve Doğa Bilimleri Dergisi, 21(6):809-816. DOI:10.18016/ksutarimdoga.vi.463813. 2018.

[33] Karaşahin M., Sade B. "Farklı Sulama Yöntemlerinin Hibrit Mısırda Dane Verimi ve Verim Unsurları Üzerine Etkileri” Uludağ Üniversitesi Ziraat Fakültesi Dergisi, 25(2), 47-56. 2011.

[34] Budak B., Soya H., “Avcıoğlu R. İzmir İli Farklı Lokasyon Koşullarında Kimi Mısır (Zea mays L.) Çeşitlerinin II. Ürün Olarak Tane Verimi ve Bazı Verim Özellikleri Üzerinde Bir Araştırma” Anadolu Journal of the Aegean Agricultural Research Institute , 24 (1), 21-28. 2014.

[35] Öner F. "Karadeniz Bölgesindeki Yerel Misır (Zea mays L.) Genotiplerinin Agronomik Ve Teknolojik Özelliklerinin Belirlenmesi”. Ondokuz Mayıs Üniversitesi, Fen Bilimleri Enstitüsü, Tarla Bitkileri Anabilim Dal, Doktora Tezi, Samsun.239s. 2011.

[36] Kaya Ç., Kuşaksız T. "Farklı Ekim Zamanlarında Yetiştirilen Mısır (Zea mays L.) Çeşitlerinde Verim ve Verimle İlgili Bazı Özelliklerin Belirlenmesi” Anadolu Journal of the Aegean Agricultural Research Institute, 22 (2) 48-58. 2012.

[37] Svecnjak Z., Varga B., Butorac J. "Yield Components of Apical and Subapical Ear Contributing to the Grain Yield Responses of Prolific Maize at High and Low Plant Populations" Journal of Agronomy and Crop Science. 192:37-42. 2006.

[38] Abendroth L. J., Elmore R. W., Boyer M. J., Marlay S. K. 2011. “Corn Growth and Development” PMR 1009, Iowa State Univ. Ext., Ames, IA, USA. 2011.

[39] Taş T. "Şanlıurfa koşullarında Bazı Atdişi Hibrit Mısır (Zea mays indentata Sturt) Çeşitlerinin Tane Özellikleri ile Tane Verimi Arasındaki İlişkilerin Belirlenmesi” ISPEC Tarım Bilimleri Dergisi, 4(2):222-233, https://doi.org/10.46291/ISPECJASvol4iss2pp87-98 2020.

[40] Çölkesen M., Öktem A., Akıncı C., Gül İ., İri R., Kaya Y. "Şanlıurfa ve Diyarbakır koşullarında bazı mısır çeşitlerinde farklı ekim zamanlarının verim ve verim komponentleri üzerine etkisi” Türkiye II. Tarla Bitkileri Kongresi, 22-25 Eylül 1997, Samsun. S, 139-142, 1997.

[41] Aygün İ., "Mısırda Aynı Genetik Tabandan Gelen Tek Melez, Üçlü Melez ve Çift Melezlerde Tane verim ve Bazı Agronomik Özelliklerin Karşılaştırılması" Selçuk Üniversitesi, Fen Bilimleri Enstitüsü, Tarla Bitkileri Anabilim Dalı Yüksek Lisans Tezi, Konya.182s. 2012.

[42] Kapar H. Öz A. "Bazı Mısır Çeşitlerinin Orta Karadeniz Bölgesinde Performanslarının Belirlenmesi” Ondokuz Mayıs Üniversitesi Ziraat Fakültesi Dergisi, 21(2):147-153, 2006.

[43] Özata E., Geçit H. H., Öz A., Ünver İkinci Karakaya S. “Atdişi Hibrit Mısır Adaylarının Ana Ürün Koşullarında Performanslarının Belirlenmesi” Iğdır Üniversitesi, Fen Bilimleri Enstitüsü Dergisi, 3(1): 91-98. 2013. 
Nevşehir Bilim ve Teknoloji Dergisi (2020), 9(2) 142-153

[44] Taş, T. "Harran Ovası Koşullarında Farklı Ekim Sıłlıklarında Yetiştirilen Mısırda (Zea mays L. indentata) Değişik Büyüme Dönemlerinde Yapılan Hasadın Silaj ve Tane Verimine Etkisi” Çukurova Üniversitesi, Fen Bilimleri Enstitüsü, Tarla Bitkileri Ana Bilim Dall, Yüksek Lisans Tezi, Adana.104s. 2010.

[45] Sabancı S. "Ege Bölgesinde Yetiştirilen Bazı Mısır (Zea mays L.) Çeşitlerinin Verim, Kalite ve Antioksidan Aktivitelerinin Belirlenmesi”, Adnan Menderes Üniversitesi, Fen Bilimleri Enstitüsü Tarla Bitkileri Anabilim Dalı Yüksek Lisans Tezi. Aydın. S.60. 2015.

[46] Ali Q., Ashraf M., Anwar F. "Seed Composition and Seed Oil Antioxidant Activity of Maize under Water Stress" Journal of the American Oil Chemists' Society, 87.1179-1187, 2010.

[47] Sumbo H. A., and Victor I. A. "Comparison of Chemical Composition, Functional Properties and Amino Acids Composition of Quality Protein Maize and Common Maize (Zea mays L)" African Journal of Food Science and Technology ((ISSN: 2141-5455) Vol. 5(3) pp. 81-89, March, 2014 DOI: http:/dx.doi.org/10.14303/ajfst.2014.024. 2014.

[48] Dumral Çağlayan N. H. "Farklı Çinko Dozlarının Mısır (Zea Mays L.) Çeşitlerinde Verim Ve Tane Kalitesi Üzerine Etkisi” Adnan Menderes Üniversitesi, Fen Bilimleri Enstitüsü, Yüksek Lisans Tezi, Aydın.85s2015.

[49] Irinkoyenikan O. A., Gbadamosi O. S., Ibironke S. I., Akanbi C.T. Taiwo K.A. "Comparative analysis of physico-chemical properties and amino acids profile of three tropical maize hybrid cultivars in Nigeria" Nutrition \& Food Science, 46 (5): 695-705. https://doi.org/10.1108/NFS-10-2015-01202016.

[50] Vaswani S., Kumar R., Kumar V., Roy D., Kumar M. "Nutritional and Mineral Composition of Different Varieties of Normal and High Quality Protein Maize Fodder at Post- Cob Stage” International Journal of Science, Environment and Technology, 5, (5): 2719 - 2727. ISSN 2278-3687, 2016.

[51] Çağlar H., Erekul O., Yiğit A. "Farklı Lokasyonlarda Yetiştirilen Mısır Çeşitlerinin Tane Verimi ve Aminoasit İçeriklerinin Belirlenmesi” Adnan Menderes Üniversitesi Ziraat Dergisi, 14(1):65-70, doi:

10.25308/aduziraat.298235, 2017.

[52] Yu X., Yu H., Zhang J., Shao S., Xiong F., Wang Z. "Endosperm Structure and Physicochemical Properties of Starches from Normal, Waxy, and Super-Sweet Maize”. International Journal of Food Properties, 18:12, 2825 2839, https://doi.org/10.1080/10942912.2015.1015732, 2015.

[53] Beckles D. M., “Thitisaksakul M. How Environmental Stress Affects Starch Composition and Functionality in Cereal Endosperm”Starch/Stärke, 66, 58-71. Doi: 10.1002/star.201300212. 2014.

[54] Lu D., Cai X.; Shi Y., Zhao J., Lu W. "Effects of Waterlogging After Pollination on the Physicochemical Properties of Starch from Waxy Maize”, Food Chemistry 2015, 179, 232-238. http://dx.doi.org/10.1016/j.foodchem.2015.01.096, 2015.

[55] Shi K., Gu X., Lu W., Lu D. "Effects of Weak-Light Stress During Grainfilling on the Physicochemical properties of Normal Maize Starch" Carbohydrate Polymers 202, 47-55. https://doi.org/10.1016/j.carbpol.2018.08.114.2018. 